\title{
Article
}

\section{Obese Patients Experience More Severe CSA than Non-Obese Patients}

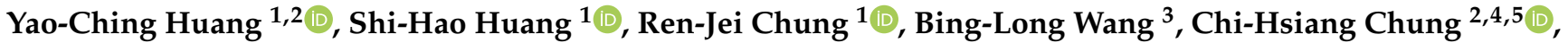 \\ Wu-Chien Chien ${ }^{2,4,5, *(\mathbb{D})}$, Chien-An Sun ${ }^{6,7} \mathbb{C}$, Pi-Ching Yu ${ }^{8,9}$ and Chieh-Hua Lu ${ }^{10, *(\mathbb{C})}$
}

1 Department of Chemical Engineering and Biotechnology, National Taipei University of Technology (Taipei Tech), Taipei 10608, Taiwan; ph870059@gmail.com (Y.-C.H.); hklu2361@gmail.com (S.-H.H.); rjchung@ntut.edu.tw (R.-J.C.)

2 Department of Medical Research, Tri-Service General Hospital, Taipei 11490, Taiwan; g694810042@gmail.com 3 School of Public Health, National Defense Medical Center, Taipei 11490, Taiwan; billwang1203@gmail.com

4 Graduate Institute of Life Sciences, National Defense Medical Center, Taipei 11490, Taiwan

5 Taiwanese Injury Prevention and Safety Promotion Association (TIPSPA), Taipei 11490, Taiwan

6 Department of Public Health, College of Medicine, Fu-Jen Catholic University, New Taipei City 242062, Taiwan; 040866@mail.fju.edu.tw

7 Big Data Center, College of Medicine, Fu-Jen Catholic University, New Taipei City 242062, Taiwan

8 Graduate Institute of Medicine, National Defense Medical Center, Taipei 11490, Taiwan; yupichin1003@gmail.com

9 Cardiovascular Intersive Care Unit, Department of Critical Care Medicine, Far-Eastern Memorial Hospital, New Taipei City 10602, Taiwan

10 Division of Endocrinology and Metabolism, Department of Internal Medicine, Tri-Service General Hospital, School of Medicine, National Defense Medical Center, Taipei 11490, Taiwan

* Correspondence: chienwu@ndmctsgh.edu.tw (W.-C.C.); undeca2001@gmail.com (C.-H.L.)

check for updates

Citation: Huang, Y.-C.; Huang, S.-H.; Chung, R.-J.; Wang, B.-L.; Chung, C.-H.; Chien, W.-C.; Sun, C.-A.; Yu, P.-C.; Lu, C.-H. Obese Patients Experience More Severe CSA than Non-Obese Patients. Int. J. Environ. Res. Public Health 2022, 19, 1289. https://doi.org/10.3390/ ijerph19031289

Academic Editor: Paul B. Tchounwou

Received: 22 December 2021

Accepted: 18 January 2022

Published: 24 January 2022

Publisher's Note: MDPI stays neutral with regard to jurisdictional claims in published maps and institutional affiliations.

Copyright: (C) 2022 by the authors. Licensee MDPI, Basel, Switzerland. This article is an open access article distributed under the terms and conditions of the Creative Commons Attribution (CC BY) license (https:// creativecommons.org/licenses/by/ $4.0 /)$.

\begin{abstract}
Objective: To investigate whether central sleep apnea (CSA) is associated with an increased risk of obesity. Materials and methods: From 1 January 2000 to 31 December 2015, we screened 24,363 obese patients from the 2005 longitudinal health insurance database, which is part of the Taiwan National Health Insurance Research Database. From the same database, 97,452 non-obese patients were also screened out. Age, gender, and index dates were matched. Multiple logistic regression was used to analyze the previous exposure risk of obese and CSA patients. A $p$-value of $<0.05$ was considered significant. Results: Obese patients were more likely to be exposed to CSA than non-obese patients would ( $\mathrm{AOR}=2.234,95 \% \mathrm{CI}=1.483-4.380, p<0.001)$. In addition, the closeness of the exposure time to the index time is positively correlated with the severity of obesity and has a dose-response effect (CSA exposure $<1$ year, AOR $=2.386$; CSA exposure $\geq 1$ year and $<5$ years, $\mathrm{AOR}=1.725$; $\mathrm{CSA}$ exposure time $\geq 5$ years, $\mathrm{AOR}=1.422$ ). The CSA exposure time of obese patients was 1.693 times that of non-obese patients. Longer exposure time is associated with more severe obesity and has a dose-response effect (CSA exposure $<1$ year, AOR $=1.420$; CSA exposure $\geq 1$ year and $<5$ years, $\mathrm{AOR}=2.240 ; \mathrm{CSA} \geq 5$ years, $\mathrm{AOR}=2.863$ ). Conclusions: In this case-control study, patients with CSA had a significantly increased risk of obesity. Long-term exposure to CSA and obesity is more likely and has a dose-response effect.
\end{abstract}

Keywords: central sleep apnea; obesity; National Health Insurance Research Database; case-control study

\section{Introduction}

Overweight and obesity are defined as abnormal or excessive fat accumulation that presents a risk to health. A body mass index (BMI) over 25 is considered overweight, and over 30 as obese [1]. Obesity is a serious disease that causes serious health damage. Obese adults have an increased risk of death due to various acute and chronic diseases (including hypertension, dyslipidemia, coronary heart disease, diabetes, gallbladder disease, gout, arthritis, and respiratory diseases) [2]. With the current growth rate, by 2025, the global obesity rate for men and women will reach $18 \%$ and $21 \%$, respectively [3]. 
According to the latest survey report of the Ministry of Health and Welfare, the obesity rate of adults ( $\geq 18$ years of age) has increased from $38 \%$ in 2009 to $43.9 \%$ in 2018 [4]. The risk of obese people suffering from diabetes mellitus (DM), metabolic syndrome, and dyslipidemia is more than three times that of people with normal weight, while the risk of suffering from hypertension, cardiovascular disease (CVD), knee arthritis, and gout is twice as much [5].

A prevalence of obstructive sleep apnea syndrome (OSAS) between 19\% and 61\% has been found in obese children and adolescents [6]. Although several studies have identified obesity as an independent risk factor for polysomnography (PSG)-confirmed OSAS, other reports have not reproduced this relationship [7,8]. It has been suggested that OSAS is independently associated with the metabolic syndrome and its components and thus OSAS is potentially an additional risk factor for the development of cardiovascular morbidity in obese children $[9,10]$.

Adenotonsillectomy as a treatment intervention for OSAS in childhood is frequently accompanied by accelerated weight gain, even in children who are overweight preoperatively [11]. A further increase in adiposity in overweight children places them at additional risk of OSAS and the adverse consequences of obesity [12]. A recent longitudinal population-based study indicated that cases of prepubertal SDB tend to resolve naturally during the transition to adolescence, but obesity was a risk factor for SDB in adolescent years $[13,14]$. As reported, sleep fragmentation and chronic inflammation status could lead to neurocognitive disorders with poor cognitive functions and memory up to degenerative diseases as Alzheimer's disease (AD) or Parkinson's [15]. The immediate deleterious effect of OSA on cognition, especially on executive function and attention, may contribute to a worsening of the AD clinical presentation [16].

Central sleep apnea (CSA) is characterized by insufficient respiratory function during sleep leading to repeated hypoventilation and impaired gas exchange [17]. Similar to obstructive sleep apnea, the clinical symptoms of CSA include fatigue, daytime sleepiness, and nocturia [18]. In addition, the proportion of CSA that stops snoring is relatively low, and the degree of lethargy is not as serious as obstructive sleep apnea [19]. CSA, similar to OSA, is associated with important complications, including frequent nocturnal awakenings, excessive daytime sleepiness, and an increased risk of cardiovascular disease. Repeated awakenings of brain waves result in sleep fragmentation, poor concentration and memory, emotional instability, daytime sleepiness, and decreased quality of life [20].

However, CSA may be a key mediating factor linking sleep disorders with chronic diseases of all ages (including CVD and DM) [21,22]. Understanding this connection may contribute to effective therapeutic interventions for sleep disorders and obesity [23,24]. At present, longitudinal observational studies on the relationship between sleep disorders and obesity are limited. Therefore, we hypothesize that central sleep apnea is related to obesity. We used the National Health Insurance Research Database (NHIRD) of the Ministry of Health and Welfare to investigate whether CSA increases the risk of subsequent obesity.

\section{Materials and Methods}

\subsection{Data Source}

Taiwan's National Health Insurance launched a single payment system on 1 March 1995. As of 2017, 99.9\% of Taiwan's population participated in the program. The data for this study comes from the 2005 Longitudinal National Health Insurance Database (LHID2005), which is part of the NHIRD, and a randomly selected 2,000,000 people from the entire population. The National Institutes of Health encrypted all personal information before they released LHID2005 to protect the privacy of the patients. In LHID2005, the disease diagnosis code is based on the "International Classification of Diseases, Ninth Revision, Clinical Modification" (ICD-9-CM) standard [23]. The research design flow chart of this study (case-control study) is shown in Figure 1. All the procedures performed in this research involving human participants comply with the ethical standards of the institution and/or the National Research Council and comply with the 1964 Declaration of Helsinki 
and its subsequent amendments or similar ethical standards. All methods were carried out following the relevant guidelines and regulations. The informed consent of all subjects was obtained; if the subject was under 18 years of age, the informed consent of the parents and/or legal guardians was obtained. The Ethical Review Board of the General Hospital of the National Defense Medical Center (TSGHIRB B-109-39) approved this study.

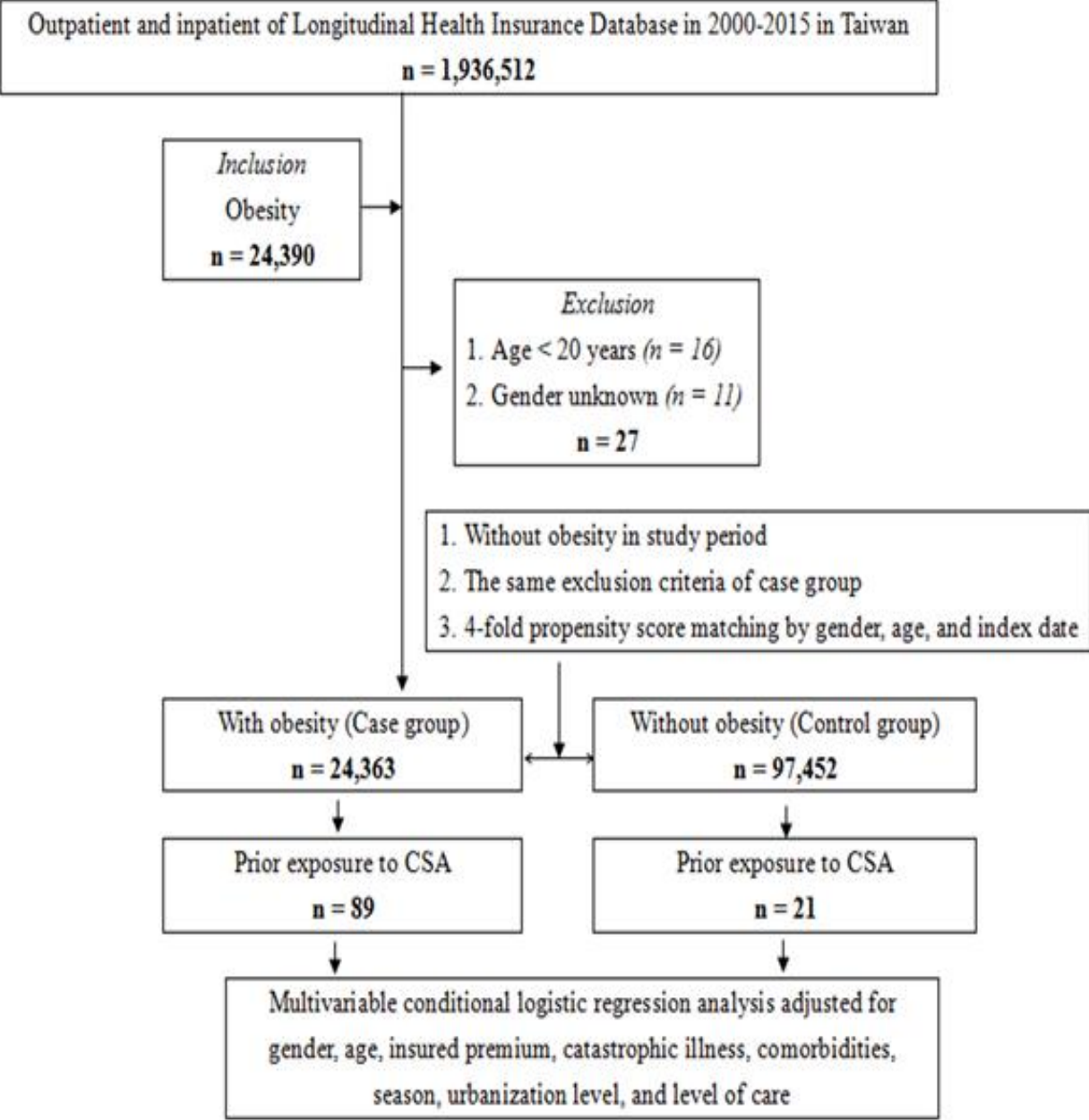

Figure 1. The flowchart of the study design from National Health Insurance Research Database in Taiwan.

\subsection{Case Group and Control Group}

The patients diagnosed as obese (ICD-9-CM code 278) constitute the obese case group. The control group consisted of patients who were not obese. The patients in the case group and the control group were matched with index date, gender, and age in a ratio of 1:4.

\subsection{Definition}

CSA, obesity, and comorbidities: The risk factor discussed in this study is CSA, which is defined based on at least three outpatient diagnoses from 2000 to 2015. The ICD-9 code 780.5 (sleep disorder) was used for identification as follows: 780.50 (sleep disorder, not specified); 780.52 (other insomnia, not specified); 780.51, 780.53, and 780.57 (sleep apnea syndrome); 307.4 (specified nonorganic sleep disorders); 780.54 (other drowsiness, not specified); 780.55 (24 h sleep-wake cycle interruption, not specified); 780.56 (dysfunction during sleep phase and waking from sleep); 780.58 (sleep-related movement disorders, unspecified); and 780.59 (sleep disorders, other).

The obesity of the patients was diagnosed according to the ICD-9 codes as follows: overweight, obesity, and other nutritional hypertrophy (ICD-9-CM code 278); overweight 
and obesity (ICD-9 CM code 278.0); morbid obesity (ICD)-9-CM code 278.01); overweight (ICD-9-CM code 278.02); and obesity hypoventilation syndrome (ICD-9-CM code 278.03).

The comorbidities evaluated in this study were DM (ICD-9-CM code 250), hypertension (ICD-9-CM code 401-405), hyperlipidemia (ICD-9-CM code 272.4), coronary heart disease (ICD-9-CM code 414.01), stroke (ICD-9-CM code 430-438), chronic heart failure (ICD-9-CM code 428.0), chronic obstructive pulmonary disease (ICD-9-CM code 490-496), chronic kidney disease (ICD-9-CM code 585), liver cirrhosis (ICD-9-CM code 571.5), tumor (ICD-9-CM code 199), anxiety (ICD-9-CM code 300.00), and depression symptoms (ICD-9-CM code 296.2-296.3, 300.4 and 311).

\subsection{Statistical Analysis}

The descriptive statistics were expressed in the form of percentages, averages, and standard deviations. The chi-square test and $t$-test were used to evaluate the distribution of categorical and continuous variables between the case and control groups. After adjusting for age, gender, education level, insurance premiums, comorbidities, Charlson's comorbidity index (CCI), season, place of residence, level of urbanization, and level of care, a conditional logistic regression analysis was performed to evaluate the CSA and the impact of obesity risk. Conditional logistic regression was used to analyze the effects of the first and last CSA exposure on obesity factors before obesity diagnosis. According to the central limit theorem, (a) if the sample data are approximately normal then the sampling distribution too will be normal; (b) in large samples (>30 or 40), the sampling distribution tends to be normal, regardless of the shape of the data; and (c) the means of the random samples from any distribution will themselves have normal distribution [25]. As the dependent variable, obesity, is a categorical variable (obese and non-obese), logistic regression requires the dependent variable to be a continuous variable before it needs to be tested for normality. All analyses were performed using SPSS version 22 (IBM, Armonk, NY, USA). A $p$-value $<0.05$ is considered to be statistically significant.

\section{Results}

The demographic data are shown in Table 1. The average age of the 121,815 patients was $44.30 \pm 15.64$ years, of which $42.77 \%$ were males and $57.23 \%$ were females. We screened 24,363 obese patients (cases) and 97,452 non-obese patients (control group). The prevalence of comorbidities in the case group was higher than in the control group. In the case group, the CCI, season, location of residence, level of urbanization, and level of care are significant.

Table 1. Characteristics of the patients.

\begin{tabular}{|c|c|c|c|c|c|c|c|}
\hline \multirow{2}{*}{$\begin{array}{c}\text { Obesity } \\
\text { Variables }\end{array}$} & \multicolumn{2}{|c|}{ Total } & \multicolumn{2}{|c|}{ With } & \multicolumn{2}{|c|}{ Without } & \multirow{2}{*}{$p$-Value } \\
\hline & $\mathbf{n}$ & $\%$ & $\mathbf{n}$ & $\%$ & n & $\%$ & \\
\hline Total & 121,815 & & 24,363 & 20.00 & 97,452 & 80.00 & \\
\hline \multicolumn{7}{|c|}{ CSA } & \multirow{3}{*}{$<0.001$} \\
\hline Without & 121,705 & 99.91 & 24,274 & 99.63 & 97,431 & 99.98 & \\
\hline With & 110 & 0.09 & 89 & 0.37 & 21 & 0.02 & \\
\hline \multicolumn{7}{|c|}{ Gender } & \multirow{3}{*}{0.999} \\
\hline Male & 52,105 & 42.77 & 10,421 & 42.77 & 41,684 & 42.77 & \\
\hline Female & 69,710 & 57.23 & 13,942 & 57.23 & 55,768 & 57.23 & \\
\hline Age (years) & \multicolumn{2}{|c|}{$44.30 \pm 15.64$} & \multicolumn{2}{|c|}{$44.25 \pm 15.53$} & \multicolumn{2}{|c|}{$44.31 \pm 15.67$} & 0.592 \\
\hline \multicolumn{7}{|c|}{ Age Group (Years) } & \multirow{4}{*}{0.999} \\
\hline $20-44$ & 74,135 & 47.48 & 14,827 & 47.48 & 59,308 & 47.48 & \\
\hline $45-64$ & 34,330 & 21.99 & 6,866 & 21.99 & 27,464 & 21.99 & \\
\hline$\geq 65$ & 47,680 & 30.54 & 9,536 & 30.54 & 38,144 & 30.54 & \\
\hline CCI_R & \multicolumn{2}{|c|}{$0.05 \pm 0.27$} & \multicolumn{2}{|c|}{$0.06 \pm 0.35$} & \multicolumn{2}{|c|}{$0.05 \pm 0.24$} & $<0.001$ \\
\hline
\end{tabular}


P: Chi-square/Fisher exact test for categorical variables, and $t$-test for continuous variables. DM, diabetes; HTN, hypertension, $\mathrm{CHD}$, coronary heart disease, $\mathrm{CHF}$, chronic heart failure, COPD, chronic obstructive pulmonary disease, CKD, chronic kidney disease.

The logistic regression of the obesity variables is shown in Table 2 . The risk of obesity in the CSA group was significantly greater than in the non-CSA group (AOR $=2.234$, $95 \% \mathrm{CI}=1.483-4.380)$. In addition, patients aged 45-64 years and over 65 have a significantly lower risk of obesity than those aged $20-44$ years $(\mathrm{AOR}=0.608,95 \% \mathrm{CI}=0.578-0.627$, $\mathrm{AOR}=0.422,95 \% \mathrm{CI}=0.397-0.446)$. On the CCI score, every increase of 1 point in the CCI score of CSA patients increases the risk of obesity by $13.8 \%$. In summer and winter, the risk of obesity was significantly reduced $(\mathrm{AOR}=0.842,95 \% \mathrm{CI}=0.804-0.885$; $\mathrm{AOR}=0.876$, 95\% CI = 0.834-0.921).

Table 2. Logistic regression of obesity variables.

\begin{tabular}{|c|c|c|c|}
\hline Variables & Adjusted OR & $95 \% \mathrm{CI}$ & $p$-Value \\
\hline \multicolumn{4}{|c|}{ CSA } \\
\hline Without & Reference & & \\
\hline With & 2.234 & $1.483-4.380$ & $<0.001$ \\
\hline \multicolumn{4}{|c|}{ Gender } \\
\hline Male & 0.862 & $0.645-1.089$ & 0.171 \\
\hline Female & Reference & & \\
\hline \multicolumn{4}{|c|}{ Age group (Years) } \\
\hline $20-44$ & Reference & & \\
\hline $45-64$ & 0.608 & $0.578-0.627$ & $<0.001$ \\
\hline$\geq 65$ & 0.422 & $0.397-0.446$ & $<0.001$ \\
\hline CCI_R & 1.138 & $1.093-1.386$ & $<0.001$ \\
\hline \multicolumn{4}{|c|}{ Season } \\
\hline Spring & Reference & & \\
\hline Summer & 0.842 & $0.804-0.885$ & $<0.001$ \\
\hline Autumn & 1.007 & $0.962-1.057$ & 0.863 \\
\hline Winter & 0.876 & $0.834-0.921$ & $<0.001$ \\
\hline
\end{tabular}

$\overline{\mathrm{OR}}=$ odds ratio, $\mathrm{CI}=$ confidence interval, adjusted $\mathrm{OR}=$ adjusted variables listed in the table.

Using logistic regression to stratify the obesity factors of the listed variables, as shown in Table 3, the obesity risk of CSA patients is 2.234 times that of the control group $(\mathrm{AOR}=2.234,95 \% \mathrm{CI}=1.483-4.380)$. The obesity risk of female CSA patients was 2.252 times that of the control group $(\mathrm{AOR}=2.252,95 \% \mathrm{CI}=1.496-4.417)$. The risk of CSA obesity in patients aged 20-44 years was significantly higher than in the control group ( $\mathrm{AOR}=2.577,95 \% \mathrm{CI}=1.713-5.054)$. Conditional logistic regression analysis showed that the risk of obesity diagnosis in the CSA group in spring ( $\mathrm{AOR}=2.547,95 \% \mathrm{CI}=1.682-4.986)$ was significantly greater than in the control group.

Table 3. Factors of obesity stratified by variables using logistic regression.

\begin{tabular}{cccc}
\hline Group & \multicolumn{3}{c}{ With CSA vs. Without CSA (Reference) } \\
\hline Stratified & Adjusted OR & $\mathbf{9 5 \%}$ CI & $p$-Value \\
\hline Overall & 2.234 & $1.483-4.380$ & $<0.001$ \\
\hline \multicolumn{5}{c}{ Gender } \\
Male & 2.213 & $1.438-4.432$ & $<0.001$ \\
Female & 2.252 & $1.496-4.417$ & $<0.001$ \\
\hline
\end{tabular}


Table 3. Cont.

\begin{tabular}{cccc}
\hline Group & \multicolumn{3}{c}{ With CSA vs. Without CSA (Reference) } \\
\hline Stratified & Adjusted OR & 95\% CI & $p$-Value \\
\hline \multicolumn{4}{c}{ Age Group (Years) } \\
\hline $20-44$ & 2.577 & $1.713-5.054$ & $<0.001$ \\
$45-64$ & 2.256 & $1.501-4.436$ & $<0.001$ \\
$\geq 65$ & 1.581 & $1.050-3.102$ & 0.001 \\
\hline \multicolumn{4}{r}{} \\
Spring & Season & $<0.001$ \\
Summer & 2.547 & $1.682-4.986$ & $<0.001$ \\
Autumn & 1.952 & $1.288-3.835$ & $<0.001$ \\
Winter & 2.556 & $1.693-5.000$ & $<0.001$ \\
\hline
\end{tabular}

Logistic regression analysis of obesity factors between exposures to CSA in different periods is shown in Figure 2. When compared with non-obese patients, obese patients are more likely to experience CSA ( $\mathrm{AOR}=2.234,95 \% \mathrm{CI}=1.483-4.380$ ). In addition, the closer the exposure time is to the obesity diagnosis time, the more the obesity severity shows a dose-response effect (CSA exposure $<1$ year, $\mathrm{AOR}=2.484,95 \% \mathrm{CI}=1.689-4.672$; $\mathrm{CSA}$ exposure $\geq 1$ year, $<5$ years, $\mathrm{AOR}=2.105,95 \% \mathrm{CI}=1.417-4.028$; $\mathrm{CSA}$ exposure $\geq 5$ years, $\mathrm{AOR}=1.862,95 \% \mathrm{CI}=1.206-3.872)$.

The last CSA exposure before the first obesity diagnosis

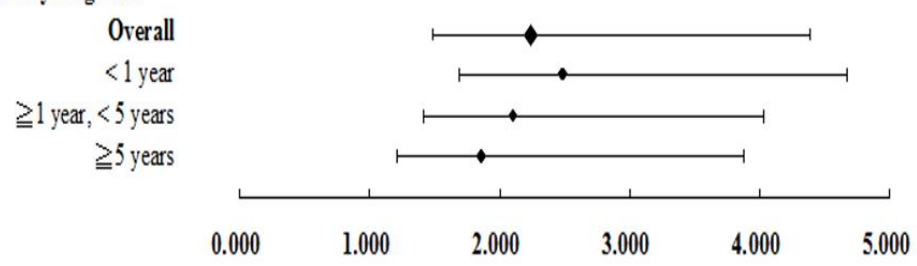

Figure 2. The last CSA exposure before the first obesity diagnosis.

Figure 3 shows that the average CSA exposure duration of obese patients is 2.234 times that of non-obese patients ( $\mathrm{AOR}=2.234,95 \% \mathrm{CI}=1.483-4.380)$. The longer the exposure time, the more severe the obesity and the dose-response effect (CSA exposure $<1$ year, $\mathrm{AOR}=2.101,95 \% \mathrm{CI}=1.312-3.879 ; \mathrm{CSA}$ exposure $\geq 1$ year, $<5$ years, $\mathrm{AOR}=2.207$, $95 \% \mathrm{CI}=1.435-4.288$; $\mathrm{CSA}$ exposure $\geq 5$ years, $\mathrm{AOR}=2.976,95 \% \mathrm{CI}=1.589-5.120$ ).

\section{The first CSA exposure to the last one before obesity diagnosis}

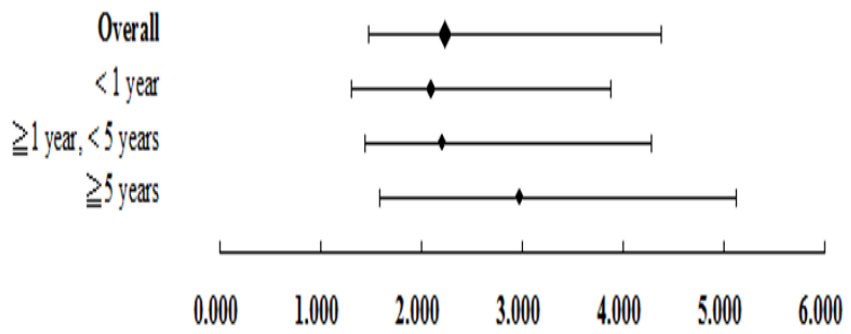

Figure 3. The first CSA exposure to the last one before obesity diagnosis.

\section{Discussion}

The results of this study show that the risk of obesity in patients aged 45-64 years or over 65 is significantly lower than in patients aged $20-44$ years. This may be due to weight loss or weight control in middle-aged and elderly people caused by the disease itself [26]. However, unknown factors may affect this result [18]. In addition, the risk of obesity in summer and winter is significantly lower than in spring, which is consistent with 
the results of Ma et al. [27]. The total daily intake in spring is higher than in autumn. The difference in the total daily intake is $222 \mathrm{kcal} /$ day [27]. Lin et al. had similar results [28]. Although the physiological mechanism of the association between CSA and obesity is unclear, we infer the underlying mechanism from previous studies, which may provide some insights for our observations. The current research literature (mainly cross-sectional and observational studies) has not yet clarified whether sleep disorders cause obesity or obesity causes sleep disorders. More research is needed, including larger sample sizes and control of confounding factors [29].

CSA encompasses a variety of breathing patterns and clinical entities. They can be classified into two categories based on the partial pressure of carbon dioxide in the arterial blood. Non-hypercapnic CSA is usually characterized by a periodic breathing pattern, while hypercapnic CSA is based on hypoventilation. The latter form of CSA is associated with disorders of the central nervous system, neuromuscular, and rib cage, as well as obesity and certain medications or substance intake [30].

Compared with OSA in clinical practice, the relationship between obesity and CSA has received less attention. The clinical feature of CSA is the repeated apnea during sleep due to temporary sleep apnea [31]. CSA represents a disorder of several breathing patterns, not caused by a single breathing pattern disorder [31]. Verhulst et al. found evidence that obesity and adipose tissue are associated with CSA, reflecting the unstable breathing pattern of CSA [32]. Verhulst et al. believe that several hypotheses can explain the interaction between obesity and CSA: obesity leads to a decrease in the volume of the chest cavity resulting in a decrease in oxygen reserves, impaired response to hypoxia and hyperventilation, and too low ventilation due to leptin resistance leading to CSA; followed by obesity, fat reduction, or folding of the upper airway. More research is needed to clarify this relationship [33-37]. CSA occurs frequently in patients with heart failure (HF) and is caused by the alternation of hyperventilation and compensatory apnea in abnormal respiratory control [38,39]. In various case reports, the frequency of CSA in HF patients exceeds OSA, ranging from $21 \%$ to $40 \%$ [40-42]. CSA is associated with increased mortality [43]. CSA patients are different from OSA patients. Patients with HF and CSA do not have upper airway collapse. CSA may be regarded as the result of HF, which seems to be related to the severity of the disease $[44,45]$. It is directly proportional to the hemodynamic severity of $\mathrm{HF}$, and nanostimulating peptides (NPs) also increase, and the increase in concentration is related to the presence of CSA $[46,47]$.

Leptin is an auxiliary agent that regulates food intake and energy expenditure [48]. Since its discovery, leptin has become known as a pectoral muscle hormone that is widely studied in the context of cardiovascular disease and is important in the supervision of ventilation control [49-51]. Human research on leptin and ventilation is mainly carried out in patients with OSA or obesity and low-ventilation syndrome [52,53]. CSA is also associated with increased chemical sensitivity to $\mathrm{CO}_{2}$ [54] and excessive ventilation during rest and exercise $[55,56]$. In vitro studies have shown that peritoneal nutrient peptide (ANP) inhibits the secretion of leptin in adipocytes. This may be mediated by the increase of guanosine monophosphate in the loop, thereby initiating lipid dissolution $[57,58]$. In addition, leptindeficient hearing/culling mice showed an increase in ventilation drive [59]. Adults with higher BMI tend to have higher serum leptin levels [60-64]. Leptin can directly act on the respiratory control center to increase the sensitivity of $\mathrm{CO}_{2}$ during sleep and subsequently prevent respiratory depression in obese subjects [65]. Therefore, the positive effect of leptin on ventilation can compensate for the increase in mechanical load and breathing disorders in obese individuals [56]. In contrast, one reason for obese hypoventilation in patients with CSA is the development of leptin resistance [66,67]. According to previous studies, the prevalence of obesity hypoventilation in adults with CSA is 13.8-20\% [68-70].

In animals lacking leptin for hyperventilation, the expression of leptin in adipocytes is reduced by intracardiac nutrient peptides (ANP), and the increase of cyclic urinary peptides (NPs) is associated with an increased risk of CSA [71]. The concentration of leptin is inversely proportional to AHI, indicating that there is a significant relationship between 
the severity of CSA and the concentration of leptin. Logistic regression analysis showed that the concentrations of leptin and BNP are closely related to the presence of CSA in high-frequency subjects [71]. Obesity may still aggravate CSA through several mechanisms, such as stimulating upper airway mechanical senses to inhibit the respiratory center in the pharynx or reducing the volume of the chest cavity to reduce oxygen storage [72,73]. Verhulst et al. proved the ability to accurately predict CSA through the BMI z-score and waist circumference [32]. A higher degree of obesity may lead to increased brain displacement of the diaphragm, thereby reducing breathing power. Therefore, in obesity patients, the protective effect of leptin and the negative impact of fat distribution on central obesity will affect the outcome of the development of CSA [31].

The integrated analysis study by Zhou et al. (2019) found there was a reverse J-shaped relationship between sleep time and obesity; with 7-8 h sleep per day, the risk of obesity is the lowest [74]. Compared with seven hours of sleep per day, individuals who sleep less than seven hours per day have a relative risk of obesity of 1.09 (95\% CI 1.05-1.14) for each hour less than seven hours; individuals with longer sleep durations have a relative risk of 1.02 (95\% CI 0.99-1.05) for each one-hour increment [74]. Short sleep time can significantly increase the risk of obesity. Compared with seven hours of sleep per day, with less than seven hours of sleep, each hour of decrease in sleep duration increases the risk of obesity by $9 \%$ [65]. Whether short-term or long-term sleep is a risk factor for obesity is the focus of debate. Two integrated analyses [75,76] explored the relationship between sleep time and the risk of obesity in adults, showing that the length of sleep has a significant relationship with the increased risk of obesity. Zhou et al. (2019) used dose-response analysis to analyze sleep, and the relationship between time and obesity risk was quantitatively assessed [74]. The research of Zhou et al. (2019) also includes more comprehensive original documents and has more rigorous methodological power to improve the accuracy and reliability of the research results [74]. In summary, the above studies seem to indicate a U-shaped correlation between sleep duration and weight gain [77]. Meanwhile, our research results show that the risk of non-obesity for CSA is 2.234 times that of patients with non-CSA. The closer the exposure time for CSA is to the obesity diagnosis time, the more serious the obesity is, and there is a dose-response effect. The risk of obesity in patients with CSA for the duration of exposure is 2.234 times that of patients with non-CSA. The longer the exposure time, the more severe the obesity; there is also a dose-response effect.

Furthermore, it is worth noting that the genes expressed in the brain at key BMIrelated sites, such as FTO, MC4R, MAP2K5, GNPDA2, PCSK1, and BDNF, may have connections with sleep time [78]. Previous studies have shown that shortened sleep time (sleep time $<7 \mathrm{~h} /$ day) increases the risk of genetic expression of high BMI (average 36.6 years) in American adults [78], resulting in different genetic effects on BMI depending on sleep times [79]. However, the mechanism by which lack of sleep increases the genetic risk on the pathogenesis of obesity is less explored. At present, adipose tissue has been identified as a dynamic endocrine organ that produces a series of biologically active substances, collectively referred to as "adipose", which regulates energy balance, inflammation, insulin resistance, and cardiovascular function [80]. Among the six genes related to leptin, three genes (MC4R, BDNF, and PCSK1) are known to be related to the hypothalamic leptin-melanin pathway [81-83].

The above pathophysiological mechanism can explain the relationship between CSA and obesity in this study. Our results show that the prevalence of CSA in obese patients is 2.34 times that of non-obese patients. In addition, the duration of CSA and the closeness to the study time is positively correlated with the severity of obesity. Therefore, it is necessary to consider the relationship between the occurrence and duration of CSA and obesity.

This study has several limitations. First, the NHIRD did not provide detailed information that might affect our survey results, such as information related to drinking, smoking, eating, and physical exercise behavior. Second, although this study was carefully designed and controlled for confounding factors, bias may still exist due to unmeasured or unknown confounding factors-for example, the onset of depression, the stage of obesity at the time 
of diagnosis, and drugs that may affect the outcome. Finally, BMI was not among the variables in our study. It is recommended that a prospective cohort study be conducted to evaluate the relationship between CSA and obesity.

\section{Conclusions}

The study showed that obese patients experience more severe CSA than non-obese patients do. Further, the proximity of CSA to the study time and the duration of exposure are positively correlated to the severity of obesity and have a dose-response effect. CSA may be a risk factor for obesity. Healthcare providers should pay close attention to the relationship between CSA and obesity risk.

Author Contributions: Y.-C.H., S.-H.H., C.-A.S., R.-J.C., P.-C.Y., W.-C.C. and C.-H.L.: conception and design, analysis and interpretation of the data, critical review, and approval of the final version submitted for publication. R.-J.C., C.-H.C., B.-L.W. and C.-H.L.: statistical analysis, critical review, and approval of the final version submitted for publication. S.-H.H., C.-A.S., Y.-C.H. and W.-C.C.: drafting of the paper, critical review, and approval of the final version submitted for publication. All authors have read and agreed to the published version of the manuscript.

Funding: This study was funded by the Tri-Service General Hospital, under grant number TSGH-B111018; TSGH-E-111246; MOST108-2314-B016-019-MY3.

Institutional Review Board Statement: The study was conducted in accordance with the Declaration of Helsinki, and approved by the Institutional Review Board of Tri-Service General Hospital(TSGHIRB B-109-39).

\section{Informed Consent Statement: Not applicable.}

Data Availability Statement: Data are available from the NHIRD published by the Taiwan NHI administration. Because of legal restrictions imposed by the government of Taiwan concerning the "Personal Information Protection Act," data cannot be made publicly available. Requests for data can be sent as a formal proposal to the NHIRD (http:/ / www.mohw.gov.tw / cht/DOS/DM1.aspx?f_list_ no $=812$ accessed on 15 October 2021).

Acknowledgments: We acknowledge the technical support in the form of the National Health Insurance research data provided by the National Health Insurance Administration, the Ministry of Health and Welfare.

Conflicts of Interest: The authors declare no conflict of interest.

\section{References}

1. World Health Organization (W.H.O.). Obesity and Overweight; World Health Organization: Geneva, Switzerland, 2021. Available online: https://www.who.int/news-room/fact-sheets/detail/obesity-and-overweight (accessed on 20 October 2021).

2. Kyrou, I.; Randevam, H.S.; Tsigos, C.; Kaltsas, G.; Weickert, M.O. Clinical Problems Caused by Obesity; Feingold, K.R., Anawalt, B., Boyce, A., Chrousos, G., de Herder, W.W., Dungan, K., Grossman, A., Hershman, J.M., Hofland, J., Kaltsas, G., Eds.; MDText.com, Inc.: South Dartmouth, MA, USA, 2000. Available online: https:/ / www.ncbi.nlm.nih.gov/books/NBK278973/ (accessed on 25 October 2021).

3. Luhar, S.; Timæus, I.M.; Jones, R.; Cunningham, S.; Patel, S.A.; Kinra, S.; Clarke, L.; Houben, R. Forecasting the prevalence of overweight and obesity in India to 2040. PLoS ONE 2020, 15, e229438. [CrossRef] [PubMed]

4. National Health Service. Ministry of Health and Welfare; National Health Service: London, UK, 2020.

5. Health Promotion Administration. Ministry of Health and Welfare; Taiwan ROC: Taipei, Taiwan, 2018. Available online: https: //www.hpa.gov.tw/File/Attach/10042/File_12271.pdf (accessed on 23 November 2021).

6. Verhulst, S.; Schrauwen, N.; Haentjens, D.; Rooman, R.; Van Gaal, L.; De Backer, W.; Desager, K. Sleep Disordered Breathing and the Metabolic Syndrome in Overweight and Obese Children and Adolescents. J. Pediatr. 2007, 150, 608-612. [CrossRef] [PubMed]

7. Redline, S.; Tishler, P.V.; Schluchter, M.D.; Aylor, J.; Clark, K.E.; Graham, G. Risk Factors for Sleep-disordered Breathing in Children. Am. J. Respir. Crit. Care Med. 1999, 159, 1527-1532. [CrossRef]

8. Verhulst, S.L.; Schrauwen, N.; Haentjens, D.; Suys, B.; Rooman, R.P.; Van Gaal, L.; De Backer, W.A.; Desager, K.N. Sleep-disordered breathing in overweight and obese children and adolescents: Prevalence, characteristics and the role of fat distribution. Arch. Dis. Child. 2007, 92, 205-208. [CrossRef]

9. Verhulst, S.L.; Schrauwen, N.; Haentjens, D.; Rooman, R.P.; Van Gaal, L.; De Backer, W.A.; Desager, K.N. Sleep duration and metabolic dysregulation in overweight children and adolescents. Arch. Dis. Child. 2008, 93, 89-90. [CrossRef] [PubMed] 
10. Wing, Y.K.; Hui, S.H.; Pak, W.M.; Ho, C.K.; Cheung, A.; Li, A.M.; Fok, T.F. A controlled study of sleep related disordered breathing in obesechildren. Arch. Dis. Child. 2003, 88, 1043-1047. [CrossRef]

11. Katz, E.S.; Moore, R.H.; Rosen, C.L.; Mitchell, R.B.; Amin, R.; Arens, R.; Muzumdar, H.; Chervin, R.D.; Marcus, C.L.; Paruthi, S.; et al. Growth after adenotonsillectomy for obstructive sleepapnea: An RCT. Pediatrics 2014, 134, 282-289. [CrossRef] [PubMed]

12. Joosten, K.F.; Larramona, H.; Miano, S.; Van Waardenburg, D.; Kaditis, A.G.; Vandenbussche, N.; Ersu, R. How do we recognize the child with OSAS? Pediatr. Pulmonol. 2017, 52, 260-271. [CrossRef]

13. Bixler, E.O.; Vgontzas, A.N.; Gaines, J.; Fernandez-Mendoza, J.; Calhoun, S.L.; Liao, D. Moderate sleep apnoea: A "silent" disorder, or not a disorder at all? Eur. Respir. J. 2016, 47, 23-26. [CrossRef]

14. Di Mauro, P.; Cocuzza, S.; Maniaci, A.; Ferlito, S.; Rasà, D.; Anzivino, R.; Vicini, C.; Iannella, G.; La Mantia, I. The Effect of Adenotonsillectomy on Children's Behavior and Cognitive Performance with Obstructive Sleep Apnea Syndrome: State of the Art. Child 2021, 8, 921. [CrossRef] [PubMed]

15. Pollicina, I.; Maniaci, A.; Lechien, J.R.; Iannella, G.; Vicini, C.; Cammaroto, G.; Cannavicci, A.; Magliulo, G.; Pace, A.; Cocuzza, S.; et al. Neurocognitive Performance Improvement after Obstructive Sleep Apnea Treatment: State of the Art. Behav. Sci. 2021, 11, 180. [CrossRef]

16. Andrade, A.G.; Bubu, O.M.; Varga, A.W.; Osorio, R.S. The Relationship between Obstructive Sleep Apnea and Alzheimer's Disease. J. Alzheimer's Dis. 2018, 64, S255-S270. [CrossRef]

17. Tung, P.; Levitzky, Y.S.; Wang, R. Obstructive, and central sleep apnea and the risk of incident atrial fibrillation in a community cohort of men and women. J. Am. Heart Assoc. 2017, 6, e004500. [CrossRef] [PubMed]

18. Drager, L.F.; McEvoy, R.D.; Barbe, F.; Lorenzi-Filho, G.; Redline, S. Sleep apnea and cardiovascular disease: Lessons from recent trials and need for team science. Circulation 2017, 136, 1840-1850. [CrossRef] [PubMed]

19. Lai, Y.J.; Lin, C.L.; Lin, M.C.; Lee, S.T.; Sung, F.C.; Chang, Y.J.; Kao, C.H. Population-based cohort study on the increase in the risk for type 2 diabetes mellitus development from non-apnea sleep disorders. Sleep Med. 2013, 14, 913-918. [CrossRef]

20. Chung, W.-S.; Lin, C.-L.; Chen, Y.-F.; Chiang, J.Y.; Sung, F.-C.; Chang, Y.-J.; Kao, C.-H. Sleep Disorders and Increased Risk of Subsequent Acute Coronary Syndrome in Individuals without Sleep Apnea: A Nationwide Population-Based Cohort Study. Sleep 2013, 36, 1963-1968. [CrossRef] [PubMed]

21. Huang, W.S.; Tsai, C.H.; Lin, C.L.; Sung, F.C.; Chang, Y.J.; Kao, C.H. Non-apnea sleep disorders are associated with subsequent ischemic stroke risk: A nationwide, population-based, retrospective cohort study. Sleep Med. 2013, 14, 1341-1347. [CrossRef]

22. Carotenuto, M.; Santoro, N.; Grandone, A.; Pascotto, C.; Perrone, L.; Del Giudice, E.M. The insulin gene variable number of tandem repeats (INS VNTR) genotype and sleep disordered breathing in childhood obesity. J. Endocrinol. Investig. 2009, 32, 752-755. [CrossRef]

23. Carotenuto, M.; Bruni, O.; Santoro, N.; del Giudice, E.M.; Perrone, L.; Pascotto, A. Waist circumference predicts the occurrence of sleep-disordered breathing in obese children and adolescents: A questionnaire-based study. Sleep Med. 2006, 7, $357-361$. [CrossRef] [PubMed]

24. Punjabi, N.M.; Shahar, E.; Redline, S.; Gottlieb, D.J.; Givelber, R.; Resnick, H.E. Sleep-Disordered Breathing, Glucose Intolerance, and Insulin Resistance: The Sleep Heart Health Study. Am. J. Epidemiology 2004, 160, 521-530. [CrossRef] [PubMed]

25. Ghasemi, A.; Zahediasl, S. Normality Tests for Statistical Analysis: A Guide for Non-Statisticians. Int. J. Endocrinol. Metab. 2012, 10, 486-489. [CrossRef] [PubMed]

26. McKee, A.; Morley, J.E. Obesity in the Elderly; Feingold, K.R., Anawalt, B., Boyce, A., Chrousos, G., de Herder, W.W., Dungan, K., Grossman, A., Hershman, J.M., Hofland, J., Kaltsas, G., Eds.; MDText.com, Inc.: South Dartmouth, MA, USA, 2000.

27. Ma, Y.; Olendzki, B.C.B.C.; Li, W.; Hafner, A.R.; Chiriboga, D.; Hebert, J.R.; Campbell, M.; Sarnie, M.; Ockene, I.S. Seasonal variation in food intake, physical activity, and body weight in a predominantly overweight population. Eur. J. Clin. Nutr. 2006, 60, 519-528. [CrossRef] [PubMed]

28. Lin, C.-L.; Liu, T.-C.; Wang, Y.-N.; Chung, C.-H.; Chien, W.-C. The Association Between Sleep Disorders and the Risk of Colorectal Cancer in Patients: A Population-based Nested Case-Control Study. Vivo 2019, 33, 573-579. [CrossRef] [PubMed]

29. Hargens, T.; Kaleth, A.; Edwards, E.; Butner, K.L. Association between sleep disorders, obesity, and exercise: A review. Nat. Sci. Sleep 2013, ume 5, 27-35. [CrossRef]

30. Herkenrath, S.D.; Randerath, W.J. More than Heart Failure: Central Sleep Apnea and Sleep-Related Hypoventilation. Respiration 2019, 98, 95-110. [CrossRef] [PubMed]

31. Chou, C.H.; Kang, K.T.; Weng, W.-C.; Lee, P.-L.; Hsu, W.-C. Central sleep apnea in obese children with sleep-disordered breathing. Int. J. Obes. 2014, 38, 27-31. [CrossRef] [PubMed]

32. Verhulst, S.L.; Schrauwen, N.; De Backer, W.A.; Desager, K.N. First night effect for polysomnographic data in children and adolescents with suspected sleep disordered breathing. Archives of Disease in Childhood 2006, 91, 233-237. [CrossRef]

33. Naimark, A.; Cherniack, R.M. Compliance of the respiratory system and its components in health and obesity. J. Appl. Physiol. 1960, 15, 377-382. [CrossRef]

34. O’Donnell, C.; Schaub, C.D.; Haines, A.S.; Berkowitz, D.E.; Tankersley, C.G.; Schwartz, A.R.; Smith, P.L. Leptin Prevents Respiratory Depression in Obesity. Am. J. Respir. Crit. Care Med. 1999, 159, 1477-1484. [CrossRef] [PubMed]

35. Pépin, J.L.; Pajon, A.; Veale, D.; Ferretti, G.; Lévy, P. Central sleep apnoea syndrome with upper airway collapse. Eur Respir 1993, 6, 592-595. 
36. Badr, M.S.; Toiber, F.R.; Skatrud, J.B.; Dempsey, J.E. Pharyngeal narrowing/occlusion during central sleep apnoea. J. Appl. Physiol. 1995, 78, 1806-1815. [CrossRef] [PubMed]

37. Vanderveken, O.M.; Oostveen, E.; Boudewyns, A.N.; Verbraecken, J.A.; Van De Heyning, P.H.; De Backer, W.A. Quantification of Pharyngeal Patency in Patients with Sleep-Disordered Breathing. ORL 2005, 67, 168-179. [CrossRef] [PubMed]

38. Bradley, T.D.; Floras, J.S. Sleep apnea and heart failure: Part II: Central sleep apnea. Circulation 2003, 107, 1822-1826. [CrossRef] [PubMed]

39. Wolk, R.; Kara, T.; Somers, V.K. Sleep-Disordered Breathing and Cardiovascular Disease. Circulation 2003, 108, 9-12. [CrossRef] [PubMed]

40. Javaheri, S.; Parker, T.J.; Liming, J.D.; Corbett, W.S.; Nishiyama, H.; Wexler, L.; Roselle, G.A. Sleep Apnea in 81 Ambulatory Male Patients With Stable Heart Failure. Circulation 1998, 97, 2154-2159. [CrossRef] [PubMed]

41. Sin, D.D.; Fitzgerald, F.; Parker, J.; Newton, G.; Floras, J.S.; Bradley, T.D. Risk Factors for Central and Obstructive Sleep Apnea in 450 Men And Women with Congestive Heart Failure. Am. J. Respir. Crit. Care Med. 1999, 160, 1101-1106. [CrossRef] [PubMed]

42. Wang, H.; Parker, J.; Newton, G.E.; Floras, J.S.; Mak, S.; Chiu, K.-L.; Ruttanaumpawan, P.; Tomlinson, G.; Bradley, T.D. Influence of Obstructive Sleep Apnea on Mortality in Patients With Heart Failure. J. Am. Coll. Cardiol. 2007, 49, 1625-1631. [CrossRef] [PubMed]

43. Naughton, M.T.; Bradley, T.D. SLEEP APNEA IN CONGESTIVE HEART FAILURE. Clin. Chest Med. 1998, 19, 99-113. [CrossRef]

44. Mansfield, D.; Kaye, D.M.; La Rocca, H.B.; Solin, P.; Esler, M.D.; Naughton, M.T. Raised Sympathetic Nerve Activity in Heart Failure and Central Sleep Apnea Is Due to Heart Failure Severity. Circulation 2003, 107, 1396-1400. [CrossRef] [PubMed]

45. Naughton, M.T.; Benard, D.C.; Liu, P.P.; Rutherford, R.; Rankin, F.; Bradley, T.D. Effects of nasal CPAP on sympathetic activity in patients with heart failure and central sleep apnea. Am. J. Respir. Crit. Care Med. 1995, 152, 473-479. [CrossRef] [PubMed]

46. Carmona-Bernal, C.; Quintana-Gallego, E.; Villa-Gil, M.; Sánchez-Armengol, A.; Martiínez-Martiínez, A.; Capote, F. Brain Natriuretic Peptide in Patients With Congestive Heart Failure and Central Sleep Apnea. Chest 2005, 127, 1667-1673. [CrossRef]

47. Calvin, A.D.; Somers, V.K.; Van Der Walt, C.; Scott, C.G.; Olson, L.J. Relation of Natriuretic Peptide Concentrations to Central Sleep Apnea in Patients With Heart Failure. Chest 2011, 140, 1517-1523. [CrossRef] [PubMed]

48. Osborn, O.; Sanchez-Alavez, M.; Brownell, S.E.; Ross, B.; Klaus, J.; Dubins, J.; Beutler, B.; Conti, B.; Bartfai, T. Metabolic Characterization of a Mouse Deficient in All Known Leptin Receptor Isoforms. Cell. Mol. Neurobiol. 2009, 30, 23-33. [CrossRef] [PubMed]

49. Karmazyn, M.; Purdham, D.M.; Rajapurohitam, V.; Zeidan, A. Leptin as a Cardiac Hypertrophic Factor: A Potential Target for Therapeutics. Trends Cardiovasc. Med. 2007, 17, 206-211. [CrossRef] [PubMed]

50. Smith, C.C.T.; Dixon, R.A.; Wynne, A.M.; Theodorou, L.; Ong, S.-G.; Subrayan, S.; Davidson, S.M.; Hausenloy, D.J.; Yellon, D.M. Leptin-induced cardioprotection involves JAK/STAT signaling that may be linked to the mitochondrial permeability transition pore. Am. J. Physiol. Circ. Physiol. 2010, 299, H1265-H1270. [CrossRef] [PubMed]

51. Malli, F.; Papaioannou, A.I.; Gourgoulianis, K.I.; Daniil, Z. The role of leptin in the respiratory system: An overview. Respir. Res. 2010, 11, 152. [CrossRef] [PubMed]

52. Makinodan, K.; Yoshikawa, M.; Fukuoka, A.; Tamaki, S.; Koyama, N.; Yamauchi, M.; Tomoda, K.; Hamada, K.; Kimura, H. Effect of Serum Leptin Levels on Hypercapnic Ventilatory Response in Obstructive Sleep Apnea. Respiration 2008, 75, $257-264$. [CrossRef] [PubMed]

53. Shimura, R.; Tatsumi, K.; Nakamura, A.; Kasahara, Y.; Tanabe, N.; Takiguchi, Y.; Kuriyama, T. Fat Accumulation, Leptin, and Hypercapnia in Obstructive Sleep Apnea-Hypopnea Syndrome. Chest 2005, 127, 543-549. [CrossRef] [PubMed]

54. Javaheri, S. A Mechanism of Central Sleep Apnea in Patients with Heart Failure. New Engl. J. Med. 1999, 341, 949-954. [CrossRef] [PubMed]

55. Arzt, M.; Harth, M.; Luchner, A.; Muders, F.; Holmer, S.R.; Blumberg, F.C.; Riegger, G.A.; Pfeifer, M. Enhanced Ventilatory Response to Exercise in Patients With Chronic Heart Failure and Central Sleep Apnea. Circulation 2003, 107, 1998-2003. [CrossRef]

56. Ribeiro, J.P. Periodic breathing in heart failure: Bridging the gap between the sleep laboratory and the exercise laboratory. Circulation 2006, 113, 9-10. [CrossRef] [PubMed]

57. Fain, J.N.; Kanu, A.; Bahouth, S.W.; Cowan, G.S.; Hiler, M.L. Inhibition of leptin release by atrial natriuretic peptide (ANP) in human adipocytes. Biochem. Pharmacol. 2003, 65, 1883-1888. [CrossRef]

58. Moro, C.; Klimcáková, E.; Lolmède, K.; Berlan, M.; Lafontan, M.; Stich, V.; Bouloumié, A.; Galitzky, J.; Arner, P.; Langin, D. Atrial natriuretic peptide inhibits the production of adipokines and cytokines linked to inflammation and insulin resistance in human subcutaneous adipose tissue. Diabetologia 2007, 50, 1038-1047. [CrossRef] [PubMed]

59. Tankersley, C.G.; O'Donnell, C.; Daood, M.J.; Watchko, J.F.; Mitzner, W.; Schwartz, A.; Smith, P. Leptin attenuates respiratory complications associated with the obese phenotype. J. Appl. Physiol. 1998, 85, 2261-2269. [CrossRef] [PubMed]

60. Considine, R.V.; Sinha, M.K.; Heiman, M.L.; Kriauciunas, A.; Stephens, T.W.; Nyce, M.R.; Ohannesian, J.P.; Marco, C.C.; McKee, L.J.; Bauer, T.L.; et al. Serum immunoreactive-leptin concentrations in normal-weight and obese humans. New Engl. J. Med. 1996, 334, 292-295. [CrossRef] [PubMed]

61. Nishimura, R.; Sano, H.; Matsudaira, T.; Miyashita, Y.; Morimoto, A.; Shirasawa, T.; Takahashi, E.; Kawaguchi, T.; Tajima, N. Childhood obesity and its relation to serum adiponectin and leptin: A report from a population-based study. Diabetes Res. Clin. Pr. 2007, 76, 245-250. [CrossRef] [PubMed] 
62. Schoppen, S.; Riestra, P.; García-Anguita, A.; López-Simón, L.; Cano, B.; De Oya, I.; De Oya, M.; Garcés, C. Leptin and adiponectin levels in pubertal children: Relationship with anthropometric variables and body composition. Clin. Chem. Lab. Med. (CCLM) 2010, 48, 707-711. [CrossRef] [PubMed]

63. Antunes, H.; Santos, C.; Carvalho, S. Serum leptin levels in overweight children and adolescents. Br. J. Nutr. 2009, 101, 1262-1266. [CrossRef] [PubMed]

64. Nishimura, R.; Sano, H.; Matsudaira, T.; Morimoto, A.; Miyashita, Y.; Shirasawa, T.; Kokaze, A.; Tajima, N. Changes in body mass index, leptin and adiponectin in Japanese children during a three-year follow-up period: A population-based cohort study. Cardiovasc. Diabetol. 2009, 8, 30. [CrossRef] [PubMed]

65. Deflandre, E.; Gerdom, A.; Lamarque, C.; Bertrand, B. Understanding Pathophysiological Concepts Leading to Obstructive Apnea. Obesity Surgery 2018, 28, 2560-2571. [CrossRef]

66. Phipps, P.R.; Starritt, E.; Caterson, I.; Grunstein, R.R. Association of serum leptin with hypoventilation in human obesity. Thorax 2002, 57, 75-76. [CrossRef] [PubMed]

67. Yee, B.J.; Cheung, J.; Phipps, P.; Banerjee, D.; Piper, A.J.; Grunstein, R. R: Treatment of Obesity Hypoventilation Syndrome and Serum Leptin. Respiration 2006, 73, 209-212. [CrossRef] [PubMed]

68. Mokhlesi, B.; Tulaimat, A.; Faibussowitsch, I.; Wang, Y.; Evans, A.T. Obesity hypoventilation syndrome: Prevalence and predictors in patients with obstructive sleep apnea. Sleep Breath. 2006, 11, 117-124. [CrossRef] [PubMed]

69. Takada, G.P.; Steiropoulos, P.; Nena, E.; Constandinidis, T.C.; Bouros, D. Prevalence and clinical characteristics of obesity hypoventilation syndrome among individuals reporting sleep-related breathing symptoms in northern Greece. Sleep Breath 2010, 14, 381-386. [CrossRef] [PubMed]

70. Verin, E.; Tardif, C.; Pasquis, P. Prevalence of daytime hypercapnia or hypoxia in patients with OSAS and normal lung function. Respir. Med. 2001, 95, 693-696. [CrossRef] [PubMed]

71. Cundrle, I.; Somers, V.K.; Singh, P.; Johnson, B.D.; Scott, C.G.; Van Der Walt, C.; Olson, L.J. Leptin deficiency promotes central sleep apnea in patients with heart failure. Chest 2014, 145, 72-78. [CrossRef]

72. Harms, C.A.; Zeng, Y.J.; Smith, C.A.; Vidruk, E.H.; Dempsey, J.A. Negative pressure-induced deformation of the upper airway causes central apnea in awake and sleeping dogs. J. Appl. Physiol. 1996, 80, 1528-1539. [CrossRef]

73. Verhulst, S.L.; Schrauwen, N.; Haentjens, D.; Van Gaal, L.; De Backer, W.A.; Desager, K.N. Reference values for sleep-related respiratory variables in asymptomatic European children and adolescents. Pediatr. Pulmonol. 2007, 42, 159-167. [CrossRef] [PubMed]

74. Zhou, Q.; Zhang, M.; Hu, D. Dose-response association between sleep duration and obesity risk: A systematic review and meta-analysis of prospective cohort studies. Sleep Breath. 2019, 23, 1035-1045. [CrossRef] [PubMed]

75. Cappuccio, F.P.; Taggart, F.M.; Kandala, N.-B.; Currie, A.; Peile, E.; Stranges, S.; Miller, M.A. Meta-Analysis of Short Sleep Duration and Obesity in Children and Adults. Sleep 2008, 31, 619-626. [CrossRef] [PubMed]

76. Wu, Y.; Zhai, L.; Zhang, D. Sleep duration and obesity among adults: A meta-analysis of prospective studies. Sleep Med. 2014, 15, 1456-1462. [CrossRef] [PubMed]

77. Tan, X.; Chapman, C.D.; Cedernaes, J.; Benedict, C. Association between long sleep duration and increased risk of obesity and type 2 diabetes: A review of possible mechanisms. Sleep Med. Rev. 2018, 40, 127-134. [CrossRef] [PubMed]

78. Fu, J.; Wang, Y.; Li, G.; Han, L.; Li, Y.; Li, L.; Feng, D.; Wu, Y.; Xiao, X.; Li, M.; et al. Childhood sleep duration modifies the polygenic risk for obesity in youth through leptin pathway: The Beijing Child and Adolescent Metabolic Syndrome cohort study. Int. J. Obes. 2019, 43, 1556-1567. [CrossRef]

79. Watson, N.F.; Harden, K.; Buchwald, D.; Vitiello, M.V.; Pack, A.; Weigle, D.S.; Goldberg, J. Sleep Duration and Body Mass Index in Twins: A Gene-Environment Interaction. Sleep 2012, 35, 597-603. [CrossRef] [PubMed]

80. Nakamura, K.; Fuster, J.J.; Walsh, K. Adipokines: A link between obesity and cardiovascular disease. J. Cardiol. 2014, 63, 250-259. [CrossRef] [PubMed]

81. Chesi, A.; Grant, S.F. The Genetics of Pediatric Obesity. Trends Endocrinol. Metab. 2015, 26, 711-721. [CrossRef] [PubMed]

82. Willer, C.J.; Speliotes, E.K.; Loos, R.J.; Li, S.; Lindgren, C.M.; Heid, I.M.; Berndt, S.I.; Elliott, A.L.; Jackson, A.U.; Lamina, C.; et al. Six new loci associated with body mass index highlight a neuronal influence on body weight regulation. Nat. Genet. 2009, 41, 25-34. [PubMed]

83. Yeo, G.S.; Farooqi, I.S.; Aminian, S.; Halsall, D.J.; Stanhope, R.G.; O’Rahilly, S. A frameshift mutation in MC4R associated with dominantly inherited human obesity. Nat. Genet. 1998, 20, 111-112. [CrossRef] [PubMed] 